\title{
The non-economic consequences of disclosure in Islamic banks
}

\author{
Dr. Sherif El-Halaby \\ Lecturer of Accounting \\ Faculty of Business Studies \\ Arab Open University, Kuwait \\ Email:sismail@aou.edu.kw \\ Professor Khaled Hussainey* \\ Professor of Accounting \\ Faculty of Business and Law \\ University of Portsmouth, United Kingdom \\ Email: khaled.hussainey@port.ac.uk \\ Dr. Heba Abou-El-Sood \\ Faculty of Commerce, \\ Cairo University, Egypt \\ Email: h.abouelsood@foc.cu.edu.eg
}

${ }^{*}$ Corresponding author 


\begin{abstract}
This paper examines the effect of sharia; social and financial (SSF) disclosure on stakeholders' loyalty towards Islamic banks. It also examines to what extent trust and satisfaction mediate this effect. It uses data collected from 600 respondents to survey questionnaires disseminated to stakeholders from 15 countries dealing with Islamic banks. Structural equation modeling (SEM) is used with a partial least squares (PLS) approach to test the research hypotheses. The results indicate that there is a significant association of disclosure on stakeholders' trust, satisfaction, and loyalty. The results also indicate that there is a partial mediating of trust and satisfaction in the relationship between disclosure and loyalty. This paper is one of the first studies examining the effect of disclosure on stakeholders' loyalty. We offer novel findings which have theoretical and practical implications for Islamic banks and their stakeholders.
\end{abstract}

Keywords Islamic banks; disclosure; external stakeholders; satisfaction; trust; loyalty; Structural Equation Modelling

\title{
Paper type Research paper
}

\section{Introduction}

The economic consequences of corporate disclosure have attracted increasing interest among academic, practitioner and policy makers. Leuz and Wysocki (2016) review prior research on the economic consequences of disclosure. They suggest that future research should go beyond the traditional capital-market effects of disclosure and examine noneconomic consequences of disclosure. In responding to Leuz and Wysocki (2016)'s suggestion, our paper has made a contribution to the literature by examining the noneconomic consequences of disclosure in Islamic banks.

We are motivated by two major aspects. Firstly, the role of (financial) services in business markets which has not been thoroughly conceptualised. Secondly, and most importantly, it is also motivated by focusing on the non-economic consequences of financial disclosure which has not been studied enough. In this study, we contribute to Islamic Accounting and Finance literature by being the first to the best of our knowledge - to examine the non-economic consequences of financial disclosure by Islamic banks.

Disclosure might have economic and/or non-economic effects. The economic consequences of disclosure studies focus on how disclosure affects stock prices, firm performance, the cost of capital and analysts' earnings forecasts accuracy. Noneconomic consequences refer to the non-financial consideration of disclosure. 
For example, in our paper, we examine how disclosure affects stakeholders' trust, satisfaction, and loyalty.

A unique feature of the confidence in Islamic banks (IBs) is their ability to convey to stakeholders that financial transactions are conducted in conformity with Islamic principles (Grais and Pellegrini, 2006). IBs faced with strong competition not only from IBs but also from conventional counterparts. When competition intensifies and banks start to offer similar products and services, the stakeholders' satisfaction, trust, and loyalty can influence the performance of IBs and determines its competitiveness and success. Hence, it is of paramount importance to assess the degree of stakeholders' satisfaction, trust, and loyalty towards Islamic banking operations. Furthermore; bank disclosure in annual reports and bank website along with other media are the main tools to deliver necessary information about Islamic banking activities to stakeholders.

We use questionnaires to collect our data. We collect 600 respondents from stakeholders in 15 countries dealing with Islamic banks. We use the structural equation modeling (SEM) with a partial least squares (PLS) approach to test our hypotheses. We find an interesting and novel result. We find evidence that there is a significant association of disclosure on stakeholders' trust, satisfaction, and loyalty. We also find that there is a partial mediating of trust and satisfaction in the relationship between disclosure and loyalty. The findings raise issues that, we believe, are salient to contemporary debates about the consequences of disclosure in Accounting and Finance literature in general and in the Islamic banking literature in particular.

The remainder of the paper is organised as follows: section 2 explores the theoretical framework of disclosure from accounting and marketing perspectives. Section 3 surveys the literature on the economic consequences of disclosure. Section 4 provides the development of research hypotheses. Section 5 introduces the research design. Section 6 presents the empirical analysis. Section 7 discusses the results. Finally, section 8 concludes. 


\section{Conceptual framework}

\subsection{Theoretical Accounting perspectives for disclosure}

Islamic banks must adhere to the regulations set by bank regulators and the Islamic principles of Sharia. Capital providers (shareholders and investors) to IBs are extremely concerned that their funds invested in a Sharia -compliant manner (Chapra and Ahmed, 2002). Thus, while agency problems in conventional companies arise when managers deviate from their duty to maximize shareholders' wealth, any divergence by managers of IBs from placing all supplied funds in Sharia -compliant investments creates an additional source of agency problems. Disclosure is considered as one of the most fundamental elements contributing to good Corporate Governance (Healy and Palepu, 2001). Availability of information is essential to minimize the information asymmetry between insiders and outsiders and to allow general investors to assess company performance (Cheung et al., 2010). Table 1 presents prior studies measuring the consequences of disclosure. Accordingly; all the studies focused on the impacts of increased disclosure mandatory or voluntary- on firm value (Elzahar et al., 2015); cost of capital (Kothari et al., 2009); analysts' forecasts (Wang et al., 2015); financial performance (Wang et al., 2008 and Platonova et al., 2016) and share price anticipation of earnings (Hussainey and Walker, 2009). Our paper, however, examines the noneconomic consequences of disclosure.

\section{[Insert table 1 about here]}

\subsection{Theoretical Marketing perspectives for loyalty, trust and satisfaction}

\subsubsection{Stakeholders Trust}

Trust is defined as a belief that the service provider can be relied on to behave in such a manner that the long-term interests of the consumers will be served (Crosby et al., 1990). In this sense, Reichheld and Schefter (2000) observe "to gain the loyalty of customers, you must first gain their trust" (p.107). The importance of trust is linked to customer loyalty (Ball et al, 2004). Moreover, trust is considered as a key to building relationships within the Banking industry as well as Islamic banking system. Trust is a dynamic and multi-faceted concept (Dimitriadis et al., 2011). In an Islamic banking context, trust is defined as a moral obligation of every individual in the 
performance of his or her duties in society. Islam places the highest emphasis on trust and considers being trustworthy as an obligatory personality trait (lqbal and Mirakhor, 2007). Thus, the foundation of the philosophy of the dimension of trust in the Islamic banking system can see as a symbol of trustworthiness, honesty, equity, equality among human beings, and moral values that established to enhance the business relationship between banks and customers (Sauer, 2002). Similarly, ethics and compliance with Sharia are highly regarded as pillars in running Islamic banking activities based on trust (Kayed and Hassan, 2011). Trust is a source of competitive advantage as it increases satisfaction. It is a fundamental asset in every business and non-business relationship (Pivato et al., 2008).

\subsubsection{Stakeholders Satisfaction}

Customer satisfaction is described by Kotler (2003) as a person's feeling of pleasure as a result of comparing a services' perceived performance with his or her prior expectations of its performance. Under this concept, consumers form expectations of product performance prior to the purchase. These expectations derived from experience with the product itself or with similar products, other marketing stimuli, and existing attitudes and confidence felt by the consumer (Moon et al., 2011). Stakeholders' satisfaction is a key issue for all organisations that wish to create and keep a competitive advantage in this highly competitive world (Fonseca, 2009). Regardless the nature of the business, the success of the banks depends on their ability to understand and satisfy their customers' needs (Selamat and Abdul-Kadir, 2012).

The importance of customer satisfaction in financial services has been studied extensively in the existing literature (Abdullah et al., 2014; Arbore and Busacca, 2009). Fonseca (2009) defines customer satisfaction as "an overall assessment of the performance of various attributes that constitute a service" (p.353). It is essential for organisation to know how satisfied their customers are in order to device successful marketing strategy and organisational development as well as discloses information related to their activities. Customer satisfaction plays a vital role in marketing because it encourages repeat sales; re-invest; stimulates positive word-of-mouth recommendations, and builds brand loyalty (Goode et al., 1996). 


\subsubsection{Stakeholders Loyalty}

Building a loyal stakeholders base is an important foundation for developing a sustainable competitive advantage. Stakeholders loyalty has been recognized over several decades for its role in the creation of many successful businesses (e.g. Kotler and Armstrong, 2008; Lewis and Soureli, 2006). Loyalty refers to a consumer's commitment to reinvest a preferred service consistently in the future. Stakeholders' loyalty has become a top priority in service industries as banks since it proven to affect profitability (Verhoef, 2003). In the banking industry, customers often develop an attitude toward purchasing behavior based on experience, which either leads to loyalty (Anthanassopoulos et al., 2001). According to Sivadass and BakerPrewitt (2000), customer loyalty is the ultimate objective of customer satisfaction measurement and found to be a key determinant of a brand's long-term viability. Loyalty is considered as an energetic aim for a firm's survival and growth. Building a loyal investor base has not only become a foremost marketing goal (Kotler and Armstrong, 2008), but it is also a significant basis for developing a sustainable competitive advantage (Dick and Basu, 1994). Compared with loyal customers, nonloyal customers are influenced by negative information about services (Donio et al., 2006).

\subsection{Development of hypotheses}

We use the information processing theory (Miller, 1956) to develop our research hypothesis. We believe that stakeholders process CSR information; Sharia compliance and financial performance to reach their decisions. Stakeholders' trust of CSR; Sharia compliance and financial performance form their expectation about banks' ability to fulfil obligations according to Sharia principals (Blomqvist, 1997). Ahmad and Haron (2002) argue that the economic and religious factors are the most important factors for customers selecting IBs. Consequently, disclosure about compliance with Sharia might influence stakeholders' satisfaction and trust towards the Sharia compliance; subsequently affecting their loyalty.

Achieving the social accountability towards the society is one of the main factors behind dealing with IBs. Haque et al (2009) find a significant positive relationship of the social perspective and confidence in the bank with customers' perception about IBs. The same results found by Dusuki and Abdullah (2007). CSR 
plays a crucial role in achieving customer loyalty and sustainable competitive advantages (Nemec, 2010). A firm's CSR practices positively affect consumer's attitude toward the corporation (Bhattacharya and Sen, 2003). A growing body of academic research finds that CSR has a positive influence on stakeholders' evaluations and purchase intentions of services (Ellen et al., 2006). The positive link between CSR and consumer patronage makes managers realize that CSR is not only an ethical/ideological imperative, but also an economic one in today's marketplace (Smith, 2000). Schwartz and Carroll (2003) state that, the bottom and largest part of the firms' accountability is maximizing the profit and creates economic value for their stakeholders. Elkington (1977) suggested that, reporting may contain information about the firm economic, financial and social impacts.

\subsection{Disclosure and loyalty}

Compliance with Sharia; social activities and good financial performance has been used in studies incorporating the loyalty. In this sense, recent studies empirically demonstrate a positive relationship between performance and customer loyalty (Perez et al., 2012). Recently, social identification theory is receiving increasing attention for customer loyalty (He et al., 2012). Mandhachitara and Poolthong (2011) find that firm' performance has a significantly strong and positive relationship with attitudinal loyalty.

Eakuru and Nik Mat (2008) studied the antecedents of customer loyalty in banks in Thailand. They viewed customer loyalty as crucial to long-term profitability, which is, can approve by disclosure. Garland (2002) identify a direct and strong relationship between customer loyalty and firm financial performance based on the profitability, while Wisskirchen et al (2006) found that long-term growth and profitability of banks rely on banks' ability to attract and retain loyal customers. Several studies have reported that CSR can positively affect consumer loyalty towards the firm (Luo and Bhattacharya, 2006). Performance as CSR and financial practices can increase loyalty (Berens et al., 2007). These results support our hypotheses that disclosure about financial results; Sharia compliance and social performance will effect on the loyalty of stakeholders.

H1: There is a significant direct association between disclosure and loyalty 


\subsection{Satisfactions (direct and mediating association)}

Literature shows a significant association between disclosure and customers' satisfaction (Bigné et al., 2011) 1 . Dusuki and Abdullah (2007) concluded that Muslim customers' satisfaction level is affected by good social responsibility practices as well as compliance with Sharia. As suggested by Heskett et al (1997), the serviceprofit firm as bank establishes relationships between financial performance, customer loyalty and satisfaction. Bernhardt et al (2000) suggest that a positive and significant relationship exists between changes in customer satisfaction and changes in financial performance of a firm. Therefore, it argues that; disclosing information about this performance for stakeholders may enhance their satisfaction level. In the banking industry, as competition increases its level, banks may be more focusing on increasing customer satisfaction through increasing the level of disclosure about the bank' performance (Goode and Moutinho, 1996). Luo and Bhattacharya (2006) found a positive link between CSR and customer satisfaction. Financial performance may contribute directly to shape the influence of satisfaction (Lam et al., 2004).

However, the effect of disclosure on other non-economic factors on satisfaction is still unexplored particularly in IBs' context Prior literature extensively tested the association between satisfaction and loyalty. For example, Othman and Owen (2001) linked satisfaction and loyalty, reporting that a satisfied customer will be loyal to the organisation, which is a measure for organisational performance. Customer satisfaction has a positive impact on customer loyalty (Amin et al., 2011). In banking context, although it recognized that customer satisfaction plays an important role in enhancing the long-term relationship between customers and the banks, customer satisfaction shown to be the better predictor of customer loyalty (Bontis et al., 2007). Ehigie (2006) concluded that satisfaction is significant determinants of customer loyalty. It stated that customer satisfaction is the most influential factor on customer loyalty (Hoq and Amin, 2010). Regarding the banking sector, Ladhari et al (2011) defined customer satisfaction as the total evaluation of the overall level of services provided with add compliance with Sharia for IBs. Chang and Chen (2008) have stated the positive linkage between satisfaction and loyalty. It

\footnotetext{
${ }^{1}$ Maignan et al (2005) suggest company's customers can be potential stakeholders who care about not only the economic performance of organizations but also to social performance. A strong record of CSR creates a favourable image that positively enhances consumers' evaluations of the firm (Bhattacharya and Sen, 2003).
} 
viewed that, consumer satisfaction and consumer loyalty as a tool to develop sustainable competitive advantage. According to Cooil et al (2007), customer satisfaction is a key determinant of long-term consumer retention. It expects that disclosure of Sharia compliance, social, and financial performance have an effect on the satisfaction of stakeholders. The previous studies supported association between satisfaction and loyalty. Combining the preceding arguments, we hypothesise a mediating of satisfaction for the relationship between disclosure and loyalty. Hence, this study set the following hypotheses:

H2: There is a significant direct link between disclosure and stakeholders' satisfaction

H3: There is a significant direct link between stakeholders' satisfaction and loyalty

H4: Stakeholders' satisfaction mediates the effect between disclosure and loyalty

\subsection{Trust (direct and mediating association)}

Similar to satisfaction, trust positively affected by the level of disclosure (Ball et al., 2004). Trust affected by the existence of values that the company and its consumer share (Morgan and Hunt, 1994). Stakeholders trust in a firm's performance and disclosure level considered to significance for firms in order for them to create value (Borglund et al., 2009). Deegan and Underman (2006) argue that the increase reporting level is part form the firms' strategy to build value then creating trust among their stakeholders' groups. For IBs; disclosure about SSF could construct and enhance stakeholders' trust. In support of this view on CSR disclosure, Pivato et al (2008:5) proposed, "The creation of trust is one of the most immediate consequences of a company's social performance or the most proximate outcome of CSR activities". As Hosmer (1994) states that firms can enhance the trust of all stakeholders by injecting ethical and responsible principles into companies' strategic decision-making processes. High levels of disclosure are more likely to attract investors, who are more trusted that stock transactions occur at "fair" prices, and thereby increase the liquidity in the firm's stock (Kim and Verrecchia, 1994). It shows repeatedly that a company's CSR policy is an antecedent of consumers trust in the company (Herault, 2012).

Stakeholders trust in an IBs context refers to stakeholders' belief that the bank will not only act in a competent and reliable manner and achieving high financial 
performance indicators, but will also fully comply with Sharia principles. This study refers to stakeholders' trust in terms of trust in the whole IBs' accountabilities. Trust considered as a determinant of loyalty particularly when a consumer perceives a relatively high degree of risk (Anderson and Srinivasan, 2003). Consumers trust in organization or its brands, not only help building loyalty, but also generate positive word of mouth (Kassim and Abdullah, 2010). Prior studies, exploring the causal linkage between trust and loyalty, considered it as the most critical factor in establishing, building and maintaining customer relationships (Chopra and Wallace, 2003). In service entities as IBs, it appears that when a customer trusts a brand (Islamic services), customers are likely to build a positive behavioural attitude towards that brand (Nguyen and Leclerc, 2011). In this respect, trust acknowledged as an important indicator in developing customer loyalty (Shainesh, 2012). A high level of trust may turn a satisfied customer into a loyal customer (Dimitriadis et al., 2011). Based on agency theory; a rich disclosure environment and low information asymmetry have many desirable consequences. These comprise the effectual allocation of resources, capital market development, liquidity in the market, reduced cost of capital, lower return volatility, and high analyst forecast accuracy (Leuz and Wysocki, 2016; Lambert et al., 2007). These consequences have a positive effect on construct the stakeholders' trust. In linking this evidence with our direct-effects hypotheses joining disclosure attributions to trust, this study expects a link between disclosure and trust. With as incentive literature about the relationship between trust and loyalty; we expect that, disclosure have a significant association with loyalty through mediating trust. As increased disclosure, level may enhance level of stakeholders' trust about IBs' compliance with Sharia as well as serving society well as Islam said in additional to achieving high financial performance. Enhancing stakeholders' trust then may increase degree of loyalty. Combining the arguments, we set the following hypotheses:

H5: Disclosure has a significant direct effect on stakeholders' trust.

H6: Stakeholders' trust has a significant direct effect on stakeholders' loyalty.

H7: Stakeholders' trust mediates effect between disclosure and loyalty.

H8: Stakeholders' trust and satisfaction mediates effect between disclosure and loyalty. 


\subsection{Methodology}

\subsection{Measurement of Constructs}

Using a multi-stage approach, this study collected data on IBs external stakeholders' perception of disclosure using a questionnaire survey design. This study initially started to measure the constructs in this study based on the analysis of prior studies in order to ensure content validity. Then, it enhanced the design by the insight gained from discussions with experts, academics and professionals, who are working in IBs. For the measurement of variables, we adopted a multiple-item 5-point Likert scale ranging from strongly disagree (1) to strongly agree (5). The scales used to measure the constructs came from the extant literature. Stakeholders' loyalty indicators were adapted from Lin and Wang (2006); Reichheld and Detrick (2003); Sirdeshmukh et al (2002); Zeithaml et al 1996); Reichheld (1993); while trust indicators were adapted from Flavian et al., (2005); Othman and Owen (2002); Morgan and Hunt (1994). Meanwhile, stakeholders' satisfaction indicators measured by adapting scales developed by Croinet et al (2000); Fornell et al (1996); Levesque and McDougall (1996). However, it modifies the questions related to satisfaction; loyalty and trust variables based on the accountability pillars for Islamic banks. Regarding the multi-faceted disclosure variable, it contains three dimensions of disclosure based on the nature of IBs; namely Sharia compliance; social and financial disclosure.

The main source for measuring disclosure is the conceptual framework that issued by IASB and contains section about the qualitative characteristics of useful financial information. For each category of disclosure, this study adopts Beest and Braam $(2012)^{2}$ and Chakroun and Hussainey (2014) approach. They measure disclosure quality based on qualitative characteristics of reporting information. This study adopts four qualitative characteristics of reporting information; which are reliability; relevance; faithful representation and understandability. The questions are

\footnotetext{
2 Beest and Braam (2012) examined whether there were differences between IFRS and US GAAP based financial reports in meeting the fundamental and enhancing qualitative characteristics for decision- usefulness as defined in the Conceptual Framework of the IASB (2015). Fundamental and enhancing qualitative characteristics are the underlying attributes which contribute to the decision usefulness of information for financial information to be useful, it must be relevant and faithfully represent what it purports to represent. The enhancing qualitative characteristics of understandability, comparability, verifiability and timeliness are complementary to the fundamental characteristics and distinguish more useful information from less useful information (IASB, 2015).
} 
adapted from Dusuki (2008); Al-Abdullatif (2007); Brown and Dacin (1997). The final measures provided in Table 2.

\section{[Insert table 2 about here]}

The questionnaires distributed to bank stakeholders. Moreover, bank managers and brokerage firm managers asked to distribute the questionnaires to their clients; investors (individual or institutional) and account holders. Furthermore, interviewers visited selected branches and distributed the questionnaires to customers outside the bank and used online and e-mail surveys to collect data. ${ }^{3}$ The total sample of stakeholders who deal with IBs includes 250 customers; 200 individual investors; 50 institutional investors and 100 accounts holders.

\subsection{Data Collection and Sample Description}

We sent out 1000 questionnaires to stakeholders who deal with IBs with 600 valid questionnaires returned (60\% response rate). The data collected based on two sources. First, it contacted several official offices with databases about IBs and their customers. Second, it contacted managers in 20 IBs located in different countries. Accordingly, it developed a cross-country dataset of stakeholders of IBs aged 21 and above in 15 countries. ${ }^{4}$ Face validity checked in this study in line with Hair et al (2009) to see if questionnaire looks valid to the respondents. For this purpose, several drafts made and reviewed with the consultation of five academics and three professionals in IBs prior to the finalization of the questionnaire. The questionnaire included a set of general questions in order to determine the perception towards the IBs accountability, identify the factors that foster or discourage dealing with IBs, and the level of trust, loyalty, and satisfaction towards the accountability of IBs. A section of the questionnaire focused on importance of disclosure about Sharia compliance, social, and financial performance to stakeholders. This study conducted a pilot test on 10 of the respondents for their comments before sending out the questionnaire to the total sample through asking them for feedback on our survey and revised questions based on their suggestions. To ensure consistency and reliability, a

\footnotetext{
${ }^{3}$ Online and e-mail surveys offer a more efficient form of data collection (Best and Krueger, 2002).

${ }^{4}$ The countries included in the cross-country dataset are UK; Egypt; KSA; Jordan; Kuwait; Qatar; Bahrain; Sudan; Yemen; Libya; Algeria; Tunisia; Syria; Malaysia and Iraq.
} 
standard definition of relevant terminologies provided on the cover page of the questionnaire.

\subsection{Data analysis and results}

\subsection{Descriptive statistics}

Table 3 displays the respondents' profile. 600 respondents surveyed. Of these 600 participants, male respondents accounted for $70 \%$ of the sample, while female respondents represented $30 \%$. The majority of respondents were aged between 31 and 40 (45\%) and 21 and 30 (42\%). In terms of educational level, $40 \%$ of the respondents had bachelor degree and $30 \%$ of the respondents had a postgraduate degree (Master level). The majority of respondents have business knowledge in accounting and finance (50\%); the main source of information on Islamic banks' performance is the annual reports $35 \%$ then websites $30 \%$. $35 \%$ of the respondents have experience of dealing with Islamic banks for more than 5 years. The main services used by the respondents are current accounts (60\%). Finally, the majority of respondent stakeholders are customers representing $42 \%$ of the sample followed by individuals' shareholders, representing $33 \%$ of the total sample. The majority of respondents come from Egypt, UK, and KSA representing 40\%, 20\%, and 10\%, respectively.

\subsection{Measurement model}

\section{[Insert table 3 about here]}

To examine the validity and reliability of our measurement model, this study uses Structural Equation Modelling (SEM) for confirmatory factor analysis along with the partial least squares (PLS) technique. Both of two techniques may provide much value for causal inquiry in communication-related and behavioural research fields. For confirmatory work, SEM and PLS preferred to be used (Benjamin and Gaskin, 2014). This study assesses the measurement model through tests of convergent validity, discriminant validity, and reliability using commonly accepted guidelines. These results presented in tables 4 and 5 . It also performs tests of multi-collinearity due to the relatively high correlations among some of the constructs. All constructs had variance inflation factors (VIF) values less than 4.75, which is within the cut off level of 5.0 (Ringle et al., 2015). As evidence of internal reliability and consistency of the construct, and following Sekaran and Bougie (2010), we use the Cronbach alpha 
coefficient and the Average Variance Extracted (AVE) (Hair et al., 2009). As shown in Table 5, the recommended threshold of 0.70 was met.

Table 5 shows the discriminant validity of the construct, since the square root of the AVE between each pair of factors was higher than the correlation estimated between factors, thus ratifying its discriminant validity (Hair et al., 2009; Bagozzi and Yi, 1998). Finally, in order to confirm the discriminant validity, we followed Fornell and Larcker (1981) who compare the correlations of the factors with the square root of the average variance extracted for each of the factors. As Table 4 shows, the square root of the average variance extracted for each factor is greater than its correlations with other factors, providing evidence for discriminant validity.

\section{[Insert table 4 about here] [Insert table 5 about here]}

\subsection{Structural model assessment}

The model explains $74 \%$ of variance for stakeholders' satisfaction, $5 \%$ of variance for trust, and $43 \%$ of variance for the loyalty towards Islamic banks. The overall fit measures suggest that the model is a plausible representation of the structures underlying the empirical data. $\mathrm{APC}=(0.428, \mathrm{p}<0.001), \mathrm{ARS}=(0.405$, $\mathrm{p}<0.001), \mathrm{AARS}=(0.403, \mathrm{p}<0.001), \mathrm{AVIF}=(2.821)$, and $\mathrm{GOF}=(0.515)$. As long as the Average Path Coefficient (APC), the Average R squared (ARS), and the Average adjusted R-squared (AARS) are significant under $1 \%$ level, and the average variance Inflation Factor (AVIF) is lower than five. As well as the geometric mean of the average communality (GOF) suggests a large effect size, the overall fit indices indicate a good fit of the model (Kock, 2011). Disclosure has a positive and significant influence on loyalty $(\beta=0.46, p<0.001)$ as suggested in $\mathrm{H} 5.8$. The results are in line with $\mathrm{H} 5.2$ that examines the effects of disclosure on stakeholders' satisfaction. They show a significant association between disclosure and satisfaction $(\beta=0.86, p<0.001)$. Results show that stakeholders' satisfaction is significantly associated with loyalty $(\beta=0.24, p<0.001$. This outcome is support H5.3. Disclosure is significantly related to trust $(\beta=0.22, p<0.001)$, giving support to H5.5. The result is in line with $\mathrm{H} 5.6$ that investigates the impacts of trust on the loyalty. It shows that, trust is significantly associated with loyalty $(\beta=0.16, p<0.001$. It seems that disclosure associations have greater influence on satisfaction than on trust. In summary, the 
significant direct effects in the model confirm that the influence of disclosure associations on loyalty mediated not only by stakeholders' satisfaction, but also by trust. The structural model indicated that disclosure, through the mediating effect of trust and satisfaction, collectively explains $43 \%$ of the variation of the variable stakeholders' loyalty for IBs. Figure 1 shows estimations for our model.

\subsection{Testing for mediation}

\section{[Insert figure 1 about here]}

We investigate the partial mediating effect of trust and satisfaction in the association between the disclosure and stakeholders' loyalty. This investigation tests H4; H7; H8. To do so, three alternative structural models in addition to the main model are estimated following the test procedures proposed by Baron and Kenney (1986). One includes disclosure only (base model), the second includes disclosure and satisfaction (Model 1), and the third includes disclosure and trust (Model 2) as well as the main model that contains disclosure; trust; satisfaction and loyalty (Full Model). As the results in table 6 indicate, the path from disclosure to loyalty in the base model is significant $(\beta=0.18, \mathrm{p}<0.001)$ which is in line with $\mathrm{H} 1$ but the indirect effect of disclosure on loyalty via satisfaction is greater than its direct effect on it $(\beta=0.36, \mathrm{p}<0.001)$ and the indirect effect of disclosure on loyalty via trust is greater than its direct effect on it $(\beta=0.27$, $\mathrm{p}<0.001)$. This result supports $\mathrm{H} 4$ that, satisfaction mediates the effect between disclosure and loyalty. Moreover; this outcome supports $\mathrm{H} 7$ that, trust mediates the relationship between disclosure and loyalty. These results are in line with H8 that support the mediating of trust and satisfaction of the relationship between disclosure and loyalty.

To further test the mediating effects, we conduct a Sobel test. The results support the mediating effects of trust $(\mathrm{p}<0.001)$ and satisfaction $(\mathrm{p}<0.001)$. The fit indices values are as follows: $\mathrm{APC}=(0.428, \mathrm{p}<0.001), \mathrm{ARS}=(0.405, \mathrm{p}<0.001), \mathrm{AARS}=(0.403, \mathrm{p}<0.001), \mathrm{AVIF}=$ (2.821), and $\mathrm{GOF}=(0.515)$. The results suggest good model fit with the data (statistically significant APC, ARS, and AARS), and low overall collinearity (AVIF < 5). The geometric mean of the average communality (GOF) suggests a large effect size. Furthermore, Cohen's (1988) affect size $f 2^{5}$. The model suggests that satisfaction $(f 2=0.739)$ has a large effect size whereas loyalty $(f 2=0.321)$ has a medium effect size and trust $(f 2=0.049)$ has a small effect size. In the

$5 f 2$ is defined as "the degree to which the phenomenon is present in the population" was used to further examine the substantive effect of the research model. Cohen (1988) suggested 0.02, 0.15, and 0.35 as operational definitions of small, medium, and large effect sizes, respectively. 
main PLS model, Stone-Geisser Q2 is 0.740 for SATIS, 0.048 for LOYA and 0.278 for TRU that is positive and hence satisfies the predictive validity of the structural model. ${ }^{6}$

\subsection{Discussion}

\section{[Insert table 6 about here]}

This study is the first one that provides novel empirical evidence on the non-economic impact of the disclosure generally and for Islamic banks particularly. The aim of this study is investigating the direct effects of disclosure on trust; satisfaction and loyalty for Islamic banks. In order to gain a better understanding of how disclosure about compliance with sharia; social and financial performance can enhance the loyalty of stakeholders who deal with Islamic banks, this study examined the critical mediating role trust and satisfaction on the association between disclosure and loyalty. Thus, we develop a comprehensive model of stakeholders' perception of disclosure based on accountability pillars of Islamic banks. Disclosure is a multi-dimensional construct composed of three dimensions which are Sharia, social, and financial. With a sample of 600 stakeholders who deal with Islamic banks cross 15 counties, the structural equation modeling results show a direct effect of disclosure on stakeholders' loyalty. The results show that there are partial mediating effects of trust and satisfaction that impact on this. Furthermore, there is a strong positive linkage between trust, satisfaction, and loyalty.

Our result supports the previous studies that measuring the association between trust; satisfaction and loyalty (Hoq and Amin, 2010; Kassim and Abdullah, 2010; Nguyen and Leclerc, 2011; Shainesh, 2012). Furthermore; our result supports as well expends scope the previous studies that measuring the impacts of disclosure on the trust, satisfaction and loyalty (Ball et al., 2004; Perez et al., 2012; Bigné et al., 2011). Our result supports the debating about the benefits of disclosure (Wang et al., 2015; Moumen et al., 2015), but with expending to non-economic consequences rather than economic (impacts on the cost of capital; firm value; analysts' forecasts and financial performance). Our result extended the scope of disclosures theories through measuring the consequences of disclosure based on primary data more

\footnotetext{
${ }^{6}$ The study tests the predictive validity of the structural model following the Stone-Geisser Q2. According to Roldán and Sánchez- Franco (2012), in order to examine the predictive validity of the research model, the cross-validated construct redundancy Q2 is necessary. A Q2 is greater than 0 implies that the model has predictive validity.
} 
than secondary data. Our findings indicate that increasing disclosure level, about Sharia, social, and financial performance through annual reports, websites, and other methods, has a significantly positive impact on external stakeholders' trust; satisfaction and loyalty.

Our paper offers a number of implications. The first practical/industry implication is that Islamic financial institutions (IFIs) may need to rethink increasing the level of disclosure to attract more customers based on their trust in the bank Sharia compliance. In the long run, however, Islamic banks should focus on disclosing information in Sharia Supervisory Board (SSB) report and CSR report to reflect the differences between these banks and conventional banks in addition to financial information. Our results are applicable to all IFls that seek to enhance their image and increase customers' loyalty as well as attract potential customers by providing better disclosure of performance. The result of this research can be used by the banking industry which seeks to enhance their image and increase customers' loyalty by providing better disclosure of the performance. Islamic Financial Institutions (IFls) need to pay attention to not just the social and financial performance in disclosure but incorporates sharia compliance aspects in disclosure to impact stakeholders' loyalty. The integrated disclosure variables positively affect stakeholders' loyalty which also attracts potential customers to IFIs. This, in the long run, contributes positively to the sustainability of Islamic banking industry. The second is a policy implication. Our findings imply that both government and the central bank should play their active role in the financial sector and forced Islamic banks to improve their disclosure levels in their annual reports because of the expected economic and non-economic benefits arise from higher levels of disclosure and transparency. The third is an academic implication, we believe that -for teaching purposes- we can highlight that financial institutions need to also pay attention to not only the social and financial performance in disclosure but incorporates sharia compliance aspects in disclosure to impact stakeholders' stakeholders' trust, satisfaction, and loyalty.

Despite the novel contributions of this study, the study contains some limitations that offer avenues for further research. First, the use of convenience sampling is one of the important shortcomings of this research. We encourage future studies to use random sampling. Second, we limited data collection to Muslim respondents because one of the main disclosure dimensions in this study is Sharia 
compliance. As an interesting extension, future research may test this conceptual model for non-Muslim respondents as well who deal with Islamic banks. Third, further research may provide separate results for different categories of stakeholders. Furthermore; the further research may add an additional variable in this model as commitment and perceived value to see to what extent increased disclosure has an impact on these variables. Mediating the effect of culture on the association between disclosure and loyalty could be investigated in the future. Finally, it is worth gaining insight on the perception of internal stakeholders, including managers and employees, towards the disclosure in Islamic banks and its effect on the investors as well all stakeholders' behaviour as trust and loyalty.

\section{References}

Abdullah, M. Hazilah, N. Manaf, A. Yusuf, M. Ahsan, K. and Azam, F. (2014). Determinants of

Customer Satisfaction on Retail Banks in New Zealand: An Empirical Analysis Using Structural Equation Modelling. Global Economy and Finance Journal, 7 (1), 63 - 82 Ahmad, N. and Haron, S. (2002). Perceptions of Malaysian corporate customers towards Islamic

banking products and services. International Journal of Islamic Financial Services, 3 (1), 13-29

Al-Abdullatif, S. (2007). The application of the AAOIFI accounting standards by the Islamic banking sector in KSA, Durham thesis, Durham University

Anderson, R. and Srinivasan, S. (2003). E-satisfaction and E-loyalty: A Contingency Framework.

Psychology \& Marketing, 20, 123-138

Anthanassopoulos, A. Gounaris, S. and Sathakopoulos, V. (2001). Behavioural responses to customer satisfaction: An empirical study. European Journal of Marketing, 35(5/6), 687-707

Arbore, A. and Busacca, B. (2009). Customer satisfaction and dissatisfaction in retail banking:

exploring the asymmetric impact of attribute performance. Journal of Retailing and Consumer Services, 16, 271-280.

Bagozzi, R. and Yi, T. (1988). On the evaluation of structural equation models. Journal of the Academy Marketing Science, 16 (1), 74-94

Ball, D. Coelho, P. and Machas, A. (2004). The role of communication and trust in explaining customer loyalty: an extension to the ECSI Model. European Journal of Marketing, $38(9 / 10), 1272-1293$

Baron, R. and Kenney, D. (1986). The moderator-mediator variable distinction in social psychological research: Conceptual, strategic, and statistical considerations. Journal of Personality and Social Psychology, 51(6), 1173-1182

Beest, F. and Braam, G. (2012). An empirical analysis of quality differences between UK annual

Reports and US 10-K reports, working paper, Radboud University Nijmegen

Best, S. and Krueger, B. (2002). New approaches to Assessing Opinion: The Prospects for Electronic Mail surveys. International Journal of Public Opinion Research, 14, 73-91

Bernhardt, K. Donthu, N. and Kennett, P. (2000). A longitudinal analysis of satisfaction and profitability. Journal of Business Research, 47, 161-171

Berens, G. Van Riel, C. and Van Rekom, J. (2007). The CSR-quality trade-off: when can 
Corporate social responsibility and corporate ability compensate each other. Journal of Business Ethics, 74, 233-252

Benjamin, P and Gaskin, J (2014). Partial Least Squares (PLS) Structural Equation Modeling (SEM) for Building and Testing Behavioural Causal Theory: When to Choose It and How to Use It. IEEE transactions on professional communication, VOL. 57, NO. 2, JUNE 2014 Bhattacharya, C. and Sen, S. (2003). Consumer-company identification: a framework for Understanding consumers' relationships with companies. Journal of Marketing, 67, April, 68-76

Bigné, E. Alvarado, A. Aldás, J. and Currás, R. (2011). Efectos de la responsabilidad social Corporativa percibida por el consumidor sobre el valor y la satisfacción con el servicio. Revista Europea de Dirección y Economía de la Empresa, 20 (4), 139-160

Blomqvist, K. (1997). The many faces of trust. Scandinavian Journal of Management, 13 (3), 271-286

Bontis, N. Booker, L. and Serenko, A. (2007). The mediating effect of organizational reputation

on customer loyalty and service recommendation in the banking industry. Management Decision, 45(9), 1425-1445

Borglund, T. De Geer, H. and Hallvarsson, M. (2009). Vardesapande CSR. Hur foretag tar socialt ansvar, sweden, falun: Nordsedts akademiska forlag

Brown, T. and Dacin, P. (1997). The company and the product: corporate associations and Consumer product responses. Journal of Marketing, 61 (1), 68-84

Chakroun, R. and Hussainey, K. (2014). Disclosure Quality in Tunisian Annual Reports. Corporate Ownership \& Control, 11(4), 58-80

Chapra, M. and Ahmed, H. (2002). Corporate Governance in Islamic Financial Institutions. Islamic Development Bank, Islamic Research and Training Institute, Periodical Document No. 6

Chang, H. and Chen, S. (2008). The impact of customer interface quality, satisfaction and Switching costs on e-loyalty: Internet experience as a moderator. Computers in Human Behaviour, 24 (6), 2927-2944

Cheung, Y. Jiang, P. and Tan, W. (2010). A Transparency Disclosure Index Measuring Disclosures: Chinese Listed Companies. Journal of Accounting and Public Policy, 29, 259-280

Chopra, K. and Wallace, W. (2003). Trust in electronic environments. Proceedings of the 36thAnnual Hawaii International Conference on System Sciences, 6-9 January, Big Island, HI, 331-40

Cohen, J. (1988). Statistical power analysis for the behavioural sciences, $2^{\text {nd }}$ ed, Hillsdale, New

$$
\text { Jersey }
$$

Cooil, B. Keiningham, T. Aksoy, L. and Hsu, M. (2007). A longitudinal analysis of customer Satisfaction and share of wallet: investigating the moderating effects of customer characteristics. J. Market, 71 (1), 67- 83

Crosby, L. Evans, K. and Cowles, D. (1990). Relationship quality in services selling: an Interpersonal influence perspective. Journal of Marketing, 54 (3), 68-81

Deegan, C. Underman, J. (2006). Financial accounting theory, European edition, McGrawHill
Education

Dimitriadis, S. Kouremenos, A. and Kyrezis, N. (2011). Trust-based segmentation preliminary

Evidence from technology-enabled bank channels. International Journal of Bank Marketing, 29 (1), 5-31

Dick, A. and Basu, K. (1994). Customer loyalty: toward an integrated conceptual framework. Journal of Academy of Marketing Science, 22 (2), 99-113

Donio, J. Massari, P. and Passiante, G. (2006). Customer satisfaction and loyalty in a digital Environment: An empirical test. Journal of Consumer Marketing, 23 (7), 445-457

Dusuki, A. and Abdullah, N. (2007). Why do Malaysian customers patronise Islamic banks?. 
International Journal of Bank Marketing, 25 (3), pp 142-160

Eakuru, N. and Nik Mat, N. (2008). The application of structural equation modelling (SEM) in Determining the antecedents of customer loyalty in banks in South Thailand. The Business Review, Cambridge, 10 (2), 129: 139

Ehigie, B. (2006). Correlates of customer loyalty to their bank: A case study in Nigeria. International Journal of Bank Marketing, 24 (7), 494 - 508

Elzahar, H. Hussainey, K. Mazzi, F. and Tsalavoutas, I. (2015). Economic consequences of Key

Performance Indicators' disclosure quality. International Review of Financial Analysis, doi: 10.1016/j.irfa.2015.03.005

Ellen, P. Web, D. and Mohr, L. (2006). Building corporate associations: Consumer attributions

for corporate social responsibility programs. Journal of the Academy of Marketing

Science, 34 (2), 147-157

Elkington, J. (1997). Cannibals with forks: the tripe bottom line of 21 st century business.

Oxford:

Capstone

Flavian, C. Guinaliu, M. and Torres, E. (2005). The influence of corporate image on consumer

Trust. Internet Research, 15 (4), 447-70

Fornell, C. Johnson, M. Anderson, E. Cha, J. and Bryant, B. (1996). The American customer satisfaction index: Nature, purpose and findings. Journal of Marketing, 60 (4), 7-18

Fornell, C. Larcker, D. (1981). Evaluating structural equation models with unobservable variables

and measurement error. Journal of Marketing Research, 18 (1), 39-50

Fonseca, J. (2009). Customer satisfaction study via a latent segment model. Journal of Retailing

and Consumer Services, 16, 352-359

Garland, R. (2002). Estimating customer defection in personal retail banking. International Journal of Bank Marketing, 20 (7), 317 - 324

Goode, M. and Moutinho, L. (1996). The effects of consumer age on overall satisfaction: an Application to financial services. Journal of Professional Services Marketing, 13 (2), 93-112

Grais, W. and Pellegrini, M. (2006). Corporate Governance in Institutions Offering Islamic Financial Services - Issues and Options, World Bank Policy Research Working Paper, 40-51

Hair, J. Black, W. Babin, B. and Anderson, R. (2009). Multivariate Data Analysis, $7^{\text {th }}$ ed, Pearson, New York, NY

Haque, I. Lone, F. and Thakur, G. (2009). Islamic banking in India: what more needed?. Journal

of Islamic Economics, Banking and Finance, 5 (3), 75-86

$\mathrm{He}, \mathrm{H}$. and Li, Y. (2011). CSR and service brand: the mediating effect of brand identification and

Moderating effect of service quality. Journal of Business Ethics, 100, 673-688

$\mathrm{He}, \mathrm{H}$. Li, Y. and Harris, L. (2012). Social identity perspective on brand loyalty. Journal of Business Research, 65, 648-657

Healy, P. and Palepu, G. (2001). Information asymmetry, corporate disclosure and capital Markets: a review of the empirical disclosure literature. Journal of Accounting and Economics, 31 (1-3), 405-440

Herault, S. (2012). Responsabilité sociale de I0entreprise et publicité. RIMHE, Rev, Interdiscip,

Manag Humanisme, 1, 7-18

Heskett, J. Sasser, W. and Schlesinger, L. (1997). The service profit chain, New York: Free Press 
Hosmer, L. (1994). Strategic planning as if ethics mattered. Strategic Management Journal, 15 ,

20-32

Hoq, M. and Amin, M, (2010). The role of customer satisfaction to enhance customer loyalty. African Journal of Business Management, 4 (12), 2385-2392

Hussainey, K. Mouselli, S. (2010). Disclosure quality and stock returns in the UK. Journal of Applied Accounting Research, 11 (2), 154-174

Hussainey, K. and Walker, M. (2009). The effects of voluntary disclosure and dividend Propensity on prices leading earnings. Accounting and Business Research, 39(1), 37-55

IASB (2010). The conceptual framework for financial reporting, September

lqbal, Z. Mirakhor, A. (2007). An Introduction to Islamic Finance: Theory and Practice, John Wiley \& Sons, Pte. Ltd

Kassim, N. and Abdullah, N. (2010). The effect of perceived service quality dimensions on Customer satisfaction, trust, and loyalty in e-commerce settings: a cross cultural analysis. Asia Pacific Journal of Marketing and Logistics, 22 (3), 351-71

Kayed, R. and Hassan, M. (2011). The global financial crisis and Islamic finance.

Thunderbird

International Business Review, 3, 551-64

Kim, O. and Verrecchia, R. (1994). Market liquidity and volume around earnings announcements.

Journal of Accounting and Economics, 17, 41-67

Kock, N. (2011). Using WarpPLS in e-collaboration studies: Descriptive statistics, settings, and

key analysis results. International Journal of e-Collaboration, 7(2), 1-18

Kotler, P. (2003). Marketing Management, Prentice-Hall, Englewood Cliffs, NJ

Kotler, P. and Armstrong, G. (2008). Principles of Marketing, $12^{\text {th }}$ ed, Pearson Education, Upper

Saddle River, NJ

Kothari, S. Li, X. and Short, J. (2009). The effect of disclosures by management, analysts, and

Financial press on cost of capital, return volatility, and analyst forecasts: a study

using content analysis. The Accounting Review, 84 (5), 1639-1670

Ladhari, R. Ladhari, I. and Morales, M. (2011). Bank service quality: comparing Canadian and

Tunisian customer perceptions. International Journal of Bank Marketing, 29 (3), 22446

Lam, S. Shankar, V. Erramilli, M. and Murthy, B. (2004). Customer value, satisfaction, loyalty, and switching costs: An illustration from a business-to-business service context. Journal of Marketing Science, 32(3), 293-311

Lambert, R. Leuz, C. and Verrecchia, R. (2007). Accounting Information, Disclosure, and the Cost of Capital. Journal of Accounting Research, 45 (2), 385-420

Leuz, C. and Wysocki, P. (2008). Economic consequences of financial reporting and disclosure

Regulation: a review and suggestions for future research. Resource document,

Social Science Research network http://papers.ssrn.com/sol3/papers.cfm?

Levesque, T. and McDougall, G. (1996). Determinants of customer satisfaction in retail banking.

International Journal of Bank Marketing, 14 (7), 12-20

Lewis, B. and Soureli, M. (2006). The antecedents of consumer loyalty in retail banking. Journal

of Consumer Behaviour, 5, 15-31

Lin, H. and Wang, Y. (2006). An examination of the determinants of customer loyalty in mobile

Commerce contextes. Information \& management, 43, 271-282 
Luo, X. and Bhattacharya, C. (2006). Corporate social responsibility, customer satisfaction, and

Market value. J. Market, 70(4), 1-18

Maignan, I. Ferrell, O. and Ferrell, L. (2005). A stakeholder model for implementing social

Responsibility in marketing. European Journal of Marketing 39 (9/10), 956-977

Miller, G. (1956). The Magical Number Seven, Plus or Minus Two Some Limits on Our Capacity

for Processing Information. Psychological Review 101(2), 343- 352

Moon, J. Crane, A. and Matten, D. (2011). Corporations and New Institutions of Global

Governance. In C. Crouch, \& C. MacLean (Eds.), the responsible corporation in a

global economy, Oxford University Press

Morgan, R. Hunt, S. (1994). The commitment-trust theory of relationship marketing. Journal

of

Marketing, 58(3), 20-38

Moumen, N. Othman, H. and Hussainey, K. (2015). The Value Relevance of Risk Disclosure in

Annual Reports: Evidence from MENA Emerging Markets (RIBAF 350). Research in International Business and Finance, http://dx.doi.org/10.1016/j.ribaf.2015.02.004

Nemec, R. (2010). Integration of corporate social responsibility into loyalty programs in the

Tourism industry. Tourism and Hospitality Management, 16 (1), 101-108

Nguyen, N. and Leclerc, A. (2011). The effect of service employees' competence on financial

Institutions' image: benevolence as a moderator variable. Journal of Services Marketing, 25 (5), 349-360

Othman A. and Owen L. (2001). Adopting and measuring customer service quality in Islamic banks: A Case Study in Kuwait Finance House. International Journal of Islamic Financial Services, 3(1), 1-26

Othman, A. and Owen, L. (2002). The multi dimensionality of carter model to measure customer

service quality in Islamic banking industry: A study in Kuwait finance house.

International Journal of Islamic Financial Services, 3(4), 1-12

Perez, A. García de los Salmones, M. and Rodríguez Del Bosque, I. (2012). The effect of

Corporate associations on consumer behaviour. European Journal of Marketing, 47

(1), 218-238

Platonova, E., Asutay, M., Dixon, R and Mohammad, S (2016). The Impact of Corporate

Social Responsibility Disclosure on Financial Performance: Evidence from the GCC Islamic

Banking Sector. Journal of Business Ethics; DOI 10.1007/s10551-016-3229-0

Pivato, S. Misani, N. and Tencati, A. (2008). The impact of corporate social responsibility on Consumer trust: the case of organic food. Bus. Ethics: Eur Rev, 17 (1), 3-12

Reichheld, F. Schefter, P. (2000). E-loyalty: Your secret weapon on the web. Harvard Business

Review, 78 (4), 105-113

Ringle, M. Wende, S, \& Becker, J. (2015). Smart PLS 3. Bönningstedt: SmartPLS. Retrieved from http://www.smartpls.com

Roldán, J. and Sánchez-Franco, M. (2012). Variance-based structural equation modelling:

Guidelines for using Partial Least Squares in information systems research.(Eds.),

Research methodologies, innovations and philosophies in software systems engineering and information systems., Hershey, PA: IGI Global., 193-221

Sauer, J. (2002). Metaphysics and economy, the problem of interest. International Journal of Social Economics, 29 (1/2), 97-118

Sekaran, U. and Bougie, R. (2010). Research methods for business: A skill building approaches

(5th ed). Chichester: John Willey \& Sons Ltd

Selamat, Z. and Abdul-Kadir, H. (2012). Attitude and patronage factors of bank customers in 
Malaysia: Muslim and Non-Muslim views. Journal of Islamic Economics, Banking and Finance, 8 (4), 87-100

Schwartz, M. and Carroll, A. (2003). Corporate social responsibility: a three-domain approach.

Business ethics quarterly, 13 (4), 503-530

Shainesh, G. (2012). Effects of trustworthiness and trust on loyalty intentions: validating a

Parsimonious model in banking. International Journal of Bank Marketing, 30 (4),

267-279

Sirdeshmukh, D. Singh, J. and Sabol, B. (2002). Consumer trust, value, and loyalty in relational

Exchanges. Journal of Marketing, 66, 15-37

Sivadass, E. and Baker-Prewitt, J. (2000). An examination of the relationship between services

Quality, customer satisfaction, and store loyalty. International Journal of Retail \&

Distribution Management, 28(2), 73-82

Smith, N. (2000). Changes in Corporate Practices in Response to Public Interest Advocacy and

Actions: The Role of Consumer Boycotts and Socially Responsible Corporate Social

Responsibility', Working Paper, London Business School, Centre for Marketing Uyar, A. and Kiliç, M. (2012). Value relevance of voluntary disclosure: evidence from Turkish

Firms. Journal of Intellectual Capital, 13 (3), 363-376

Verhoef, P. (2003). Understanding the effect of customer relationship management efforts on

Customer retention and customer share development. Journal of Marketing, 67 (4), 30-45

Wang, Y. Chen, Y. and Wang, J. (2015). Management earnings forecasts and analyst forecasts:

Evidence from mandatory disclosure system. China Journal of Accounting Research, 8, 133-146

Wang, K. Sewon, O. and Claiborne, C. (2008). Determinants and consequences of voluntary Disclosure in an emerging market: evidence from China. Journal of International

Accounting, Auditing and Taxation, 17 (1), 14-30

Wisskirchen, C. Vater, D. Wright, T. De Backer, P. and Detrick, C. (2006). The customer-led

Bank: converting customers from defectors into fans. Stra. And Leadership, 34 (2), $10-20$

Zeithaml, V. Berry, L. and Parasuraman, A. (1996). The behavioural consequences of service

Quality. Journal of Marketing, 60 (2), 31-46

\section{Tables}

Table 1: The economic consequences for increased disclosure

\begin{tabular}{|c|c|c|c|}
\hline Studies & Research Issue & Country & Findings \\
\hline Elzabar et al., 2015 & $\begin{array}{l}\text { Economic consequences of Key } \\
\text { Performance Indicators' disclosure quality }\end{array}$ & $U K$ & $\begin{array}{l}\text { We find a significantly negative (weakly positive) relationship between disclosure } \\
\text { quality of financial KPIs and the implied cost of capital (firm value). }\end{array}$ \\
\hline Moumen et al., 2015 & $\begin{array}{l}\text { The Value Relevance of Disclosure in } \\
\text { Annual Reports }\end{array}$ & $\begin{array}{l}\text { MENA } \\
\text { countries }\end{array}$ & $\begin{array}{l}\text { Found a positive relationship between voluntary disclosure information and the } \\
\text { market's ability to anticipate two-year abead future earnings change. It approves the } \\
\text { usefulness of disclosure in annual reports. }\end{array}$ \\
\hline Wang et al., 2015 & $\begin{array}{l}\text { Management earnings forecasts and } \\
\text { analyst forecasts }\end{array}$ & China & $\begin{array}{l}\text { Showed that such selective disclosure negatively influences analysts' forecasts and } \\
\text { reduces analyst following and forecast accuracy. }\end{array}$ \\
\hline Miibkinen, 2013 & $\begin{array}{l}\text { The usefulness of firm risk disclosures } \\
\text { under different firm riskiness, investor- } \\
\text { interest, and market conditions }\end{array}$ & Finland & It found that momentum in stock markets affects the relevance of firms' risk reports \\
\hline Uyar and Kilic, 2012 & Value relevance of voluntary disclosure & Turkey & $\begin{array}{l}\text { Voluntary disclosure is value-relevant; i.e. influences firm value. Therefore, this } \\
\text { finding might accepted as a signal to corporations to disclose more information to the } \\
\text { stakeholders. }\end{array}$ \\
\hline
\end{tabular}




\begin{tabular}{|c|c|c|c|}
\hline Jiao, 2011 & $\begin{array}{l}\text { Corporate Disclosure, Market Valuation, } \\
\text { and Firm Performance }\end{array}$ & $U S A$ & $\begin{array}{l}\text { A positive and significant relationships between the AIMR rankings on firms' } \\
\text { mandatory and voluntary disclosures and stock returns, market valuation, future } \\
\text { operating performance, and future Randd intensity. }\end{array}$ \\
\hline $\begin{array}{l}\text { Hussainey and } \\
\text { Mouselli, } 2010\end{array}$ & $\begin{array}{l}\text { The link between accounting information } \\
\text { and disclosure quality }\end{array}$ & $U K$ & $\begin{array}{l}\text { Showed that future-oriented earnings statements in the annual report narratives } \\
\text { increase the stock market's ability to anticipate future earnings change three years } \\
\text { abead. }\end{array}$ \\
\hline Cheung et al., 2010 & $\begin{array}{l}\text { Transparency matters among Chinese } \\
\text { listed companies }\end{array}$ & China & $\begin{array}{l}\text { There is a positive and significant relation between company transparency and } \\
\text { market valuation }\end{array}$ \\
\hline Kothari et al., 2009 & $\begin{array}{l}\text { The effect of disclosures by business press, } \\
\text { management on cost of capital, return } \\
\text { volatility, and analyst forecasts }\end{array}$ & $U S A$ & $\begin{array}{l}\text { Found that when content analysis indicates favourable disclosures, the firm's risk, } \\
\text { as proxies by the cost of capital, stock return volatility, and analyst forecast } \\
\text { dispersion, declines significantly. Unfavourable disclosures accompanied by } \\
\text { significant increases in risk measures }\end{array}$ \\
\hline $\begin{array}{l}\text { Hussainey and } \\
\text { Walker, } 2009\end{array}$ & $\begin{array}{l}\text { The effects of voluntary disclosure and } \\
\text { dividend propensity on prices leading } \\
\text { earnings }\end{array}$ & $U K$ & $\begin{array}{l}\text { Found that share price anticipation of earnings improves with increasing levels of } \\
\text { annual report narrative disclosure, and that firms that pay dividends exbibit higher } \\
\text { levels of share price anticipation of earnings than non-dividend-paying firms }\end{array}$ \\
\hline Hassan et al., 2009 & $\begin{array}{l}\text { The association between mandatory and } \\
\text { voluntary disclosures and firm vale }\end{array}$ & Egypt & $\begin{array}{l}\text { It shows highly significant negative association between mandatory disclosure and } \\
\text { firm value. Also showed a weaker positive relationship between voluntary disclosure } \\
\text { and firm value }\end{array}$ \\
\hline Wang et al., 2008 & $\begin{array}{l}\text { Determinants and consequences of } \\
\text { voluntary disclosure in an emerging } \\
\text { market }\end{array}$ & China & $\begin{array}{l}\text { Found a significant positive relationship between voluntary disclosure and a } \\
\text { company's financial performance measured by return on equity }\end{array}$ \\
\hline Haggard et al., 2008 & $\begin{array}{l}\text { Does voluntary disclosure improve stock } \\
\text { price informativeness }\end{array}$ & $U S A$ & $\begin{array}{l}\text { The disclosure improves investors access to firm-specific information and makes } \\
\text { stock prices more informative, which may in turn improve the efficiency of corporate } \\
\text { governance and firm investment }\end{array}$ \\
\hline $\begin{array}{l}\text { Da Silva and Alves, } \\
2004\end{array}$ & $\begin{array}{l}\text { The existence of associations between } \\
\text { voluntary disclosure of financial } \\
\text { information on the Internet and Firm } \\
\text { value }\end{array}$ & $\begin{array}{l}\text { Argentina, } \\
\text { Brazil, } \\
\text { Mexico }\end{array}$ & $\begin{array}{l}\text { The disclosure of financial information on the Internet obtained greater market } \\
\text { values. The disclosure of financial information on the Web can maximize the firm } \\
\text { value as the investors have easy access to the source of information in order to make } \\
\text { decisions of investment. }\end{array}$ \\
\hline
\end{tabular}

\section{Table 2: Measurement of Construct}

\begin{tabular}{|c|c|c|}
\hline Factors & Items & Sources \\
\hline $\begin{array}{l}\text { Stakebolders } \\
\text { Satisfaction }\end{array}$ & $\begin{array}{l}\text { - I am satisfied with my bank's financial performance } \\
\text { - I am satisfied with services provided by my bank } \\
\text { - I am satisfied with compliance of my bank with Islamic sharia } \\
\text { - I am satisfied with my bank's accountability towards the society }\end{array}$ & $\begin{array}{l}\text { Fornell et al., 1996; Levesque and } \\
\text { McDougall, } 1996\end{array}$ \\
\hline $\begin{array}{l}\text { Stakeholders } \\
\text { Trust }\end{array}$ & $\begin{array}{l}\text { - I have a trust that my Islamic bank is truly concerned with Islamic principles } \\
\text { - I have a confidence and trust in Bank's Sharia advisors } \\
\text { - I believe that my Islamic bank serving society well } \\
\text { - I have a confidence and trust in Bank's staff and Bank's management }\end{array}$ & $\begin{array}{l}\text { Flavian et al., 2005; Othman and } \\
\text { Owen, 2002; Morgan and Hunt, 1994; } \\
\text { Sirdeshmukh et al., 2002; Ellen et al., } \\
\text { 2006; Osterhus, } 1997\end{array}$ \\
\hline $\begin{array}{l}\text { Stakeholders } \\
\text { loyalty }\end{array}$ & $\begin{array}{l}\text { - I will say positive things about Islamic banks to other people } \\
\text { - I will recommend family and relatives to do business with Islamic bank } \\
\text { - I recommend Islamic banks to someone who seeks advice } \\
\text { - I continue to do more business with Islamic banks }\end{array}$ & $\begin{array}{l}\text { Zeithaml et al., 1996; Sirdeshmukh et } \\
\text { al., } 2002\end{array}$ \\
\hline Disclosure & $\begin{array}{l}\text { Sharia Disclosure } \\
\text { - I rely on SSBR to be sure about compliance with sharia for my bank } \\
\text { - The annual report as well as website provide sufficient and complete information about compliance with } \\
\text { Islamic sharia } \\
\text { - To what extent are the SSBR sufficiently clear? } \\
\text { - For what extent Zakat and Sadakat statement is important for you (added value for you) and making } \\
\text { differences in your decisions through dealing with Islamic banks } \\
\text { - For what extent SSBR is important for you (added value for you) and making differences in your } \\
\text { decisions through dealing with Islamic banks } \\
\text { - For what extent Internal auditing sharia department report is important for you and making differences } \\
\text { in your decisions through dealing with IBs } \\
\text { Social Disclosure } \\
\text { - I rely on CSR to be sure about serving my bank the society } \\
\text { - The annual report as well as website provide sufficient and complete information about serving society } \\
\text { (charity and donations) } \\
\text { - To what extent are the CSRR sufficiently clear? } \\
\text { - For what extent Qard Hassan statement is important for you (added value for you) and making }\end{array}$ & $\begin{array}{l}\text { Beest and Braam, 2012; Chakroun and } \\
\text { Hussainey, } 2014 \text { approach and } \\
\text { questions adopted from Brown and } \\
\text { Dacin, } 1997\end{array}$ \\
\hline
\end{tabular}




differences in your decisions through dealing with Islamic banks
- For what extent CSR report is important for you (added value for you) and making differences in your
decisions through dealing with Islamic banks
Financial Disclosure
- I rely on financial statements to be sure about financial performance for my bank
- The annual report as well as website provide sufficient and complete information about the financial
performance and profitability
- To what extent are the FS sufficiently clear?
- For what extent Financial statements as profit and loss account and balance sheet are important for
you (added value for you) and making differences in your decisions through dealing with Islamic banks

Table 3: Descriptive statistics of respondent characteristics

\begin{tabular}{|c|c|c|c|c|c|c|c|}
\hline Variable & Categories & Frequency & $\%$ & Variable & Categories & Frequency & $\%$ \\
\hline Gender & $\begin{array}{l}\text { Male } \\
\text { Female }\end{array}$ & $\begin{array}{l}420 \\
180\end{array}$ & $\begin{array}{l}70 \% \\
30 \%\end{array}$ & Age & $\begin{aligned} 21 & >30 \\
31 & >40 \\
41 & >50 \\
& >50\end{aligned}$ & $\begin{array}{c}252 \\
270 \\
60 \\
18\end{array}$ & $\begin{array}{c}42 \% \\
45 \% \\
10 \% \\
3 \%\end{array}$ \\
\hline Education & $\begin{array}{l}\text { Bachelor degree } \\
\text { Diploma } \\
\text { Master } \\
\text { Doctorate } \\
\text { Other }\end{array}$ & $\begin{array}{c}240 \\
90 \\
180 \\
60 \\
30\end{array}$ & $\begin{array}{l}40 \% \\
15 \% \\
30 \% \\
10 \% \\
5 \%\end{array}$ & $\begin{array}{l}\text { Key knowledge } \\
\text { and } \\
\text { background }\end{array}$ & $\begin{array}{l}\text { Sharia } \\
\text { Business } \\
\text { Other }\end{array}$ & $\begin{array}{c}90 \\
300 \\
210\end{array}$ & $\begin{array}{l}15 \% \\
50 \% \\
35 \%\end{array}$ \\
\hline $\begin{array}{l}\text { Main sources of } \\
\text { information about } \\
\text { IBs }\end{array}$ & $\begin{array}{l}\text { Annual reports } \\
\text { Websites } \\
\text { Friends } \\
\text { TV } \\
\text { Others }\end{array}$ & $\begin{array}{c}210 \\
180 \\
60 \\
30 \\
120\end{array}$ & $\begin{array}{c}35 \% \\
30 \% \\
10 \% \\
5 \% \\
20 \%\end{array}$ & $\begin{array}{l}\text { Years of } \\
\text { Experience in } \\
\text { Dealing with } \\
\text { IBs }\end{array}$ & $\begin{array}{l}<1 \\
1<3 \\
3<5 \\
>5\end{array}$ & $\begin{array}{c}90 \\
150 \\
150 \\
210\end{array}$ & $\begin{array}{l}15 \% \\
25 \% \\
25 \% \\
35 \%\end{array}$ \\
\hline $\begin{array}{l}\text { Kind of services } \\
\text { used by } \\
\text { respondents }\end{array}$ & $\begin{array}{l}\text { Current account } \\
\text { Murababa } \\
\text { Musharaka } \\
\text { Mudaraba } \\
\text { Other }\end{array}$ & $\begin{array}{c}360 \\
90 \\
30 \\
30 \\
90\end{array}$ & $\begin{array}{l}60 \% \\
15 \% \\
5 \% \\
5 \% \\
15 \%\end{array}$ & Countries & $\begin{array}{l}U K \\
\text { Egypt } \\
K S A \\
\text { Jordan } \\
\text { Kuwait }\end{array}$ & $\begin{array}{c}120 \\
240 \\
60 \\
18 \\
30\end{array}$ & $\begin{array}{c}20 \% \\
40 \% \\
10 \% \\
3 \% \\
5 \%\end{array}$ \\
\hline $\begin{array}{l}\text { Kind of } \\
\text { stakeholders }\end{array}$ & $\begin{array}{l}\text { Customers } \\
\text { Accounts Holders } \\
\text { Individual shareholders } \\
\text { Institutional shareholders }\end{array}$ & $\begin{array}{c}240 \\
100 \\
200 \\
50\end{array}$ & $\begin{array}{c}42 \% \\
17 \% \\
33 \% \\
8 \%\end{array}$ & & $\begin{array}{l}\text { Qatar } \\
\text { Babrain } \\
\text { Sudan } \\
\text { Yemen } \\
\text { Libya } \\
\text { Algeria } \\
\text { Tunisia } \\
\text { Syria } \\
\text { Malaysia } \\
\text { Iraq }\end{array}$ & $\begin{array}{c}12 \\
12 \\
6 \\
18 \\
6 \\
24 \\
12 \\
6 \\
12 \\
24\end{array}$ & $\begin{array}{l}2 \% \\
2 \% \\
1 \% \\
3 \% \\
1 \% \\
4 \% \\
2 \% \\
1 \% \\
2 \% \\
4 \%\end{array}$ \\
\hline
\end{tabular}

Table 4: Loadings and cross-loadings of measurement items

\begin{tabular}{|l|l|l|l|l|l|}
\hline & \multicolumn{1}{|c|}{$\boldsymbol{S A T I S}$} & \multicolumn{1}{|c|}{ TRUS } & \multicolumn{1}{|c|}{ LOYA } & \multicolumn{1}{|c|}{ DISC } & $\boldsymbol{P}_{\text {value }}$ \\
\hline SATIS1 & $\mathbf{0 . 6 9 9}$ & -0.009 & 0.274 & -0.913 & $<0.001$ \\
\hline SATIS2 & $\mathbf{0 . 7 2 7}$ & -0.018 & 0.198 & -1.162 & $<0.001$ \\
\hline SATIS3 & $\mathbf{0 . 8 1 9}$ & -0.003 & -0.145 & 0.548 & $<0.001$ \\
\hline SATIS4 & $\mathbf{0 . 8 4 2}$ & 0.019 & -0.187 & 0.514 & $<0.001$ \\
\hline TRUS1 & 0.062 & $\mathbf{0 . 7 9 8}$ & 0.027 & -0.077 & $<0.001$ \\
\hline TRUS2 & 0.079 & $\mathbf{0 . 8 4 1}$ & 0.041 & -0.073 & $<0.001$ \\
\hline TRUS3 & -0.182 & $\mathbf{0 . 7 7 8}$ & -0.065 & 0.180 & $<0.001$ \\
\hline TRUS4 & 0.029 & $\mathbf{0 . 8 7 4}$ & -0.006 & -0.019 & $<0.001$ \\
\hline LOYA1 & 0.041 & 0.086 & $\mathbf{0 . 8 4 7}$ & -0.072 & $<0.001$ \\
\hline LOYA2 & 0.161 & -0.014 & $\mathbf{0 . 8 5 9}$ & -0.196 & $<0.001$ \\
\hline LOYA3 & 0.121 & -0.033 & $\mathbf{0 . 8 6 7}$ & -0.229 & $<0.001$ \\
\hline LOYA4 & -0.389 & -0.045 & $\mathbf{0 . 7 3 1}$ & 0.601 & $<0.001$ \\
\hline DISC1 (6) & -0.541 & -0.155 & 0.553 & $\mathbf{0 . 7 3 3}$ & $<0.001$ \\
\hline DISC2 (5) & 0.180 & 0.064 & -0.227 & $\mathbf{0 . 9 5 1}$ & $<0.001$ \\
\hline DISC3 (4) & 0.176 & 0.038 & -0.138 & $\mathbf{0 . 9 7 4}$ & $<0.001$ \\
\hline
\end{tabular}


Table 5: Results of composite reliability and convergent/discriminant validity testing

\begin{tabular}{|c|c|c|c|c|c|c|c|c|}
\hline \multirow[t]{2}{*}{ Construct } & \multirow[t]{2}{*}{ Reliability } & \multirow[t]{2}{*}{ Cronbach's $\alpha$} & \multirow[t]{2}{*}{$\boldsymbol{A V E}$} & \multirow[t]{2}{*}{ Collinearity VIFs } & \multicolumn{4}{|c|}{ Correlations and square roots of AVEs } \\
\hline & & & & & SATIS & $T R U$ & $L O Y A$ & DISC \\
\hline SATIS & 0.799 & 0.763 & 0.513 & 4.058 & 0.716 & & & \\
\hline TRU & 0.894 & 0.841 & 0.678 & 1.055 & 0.156 & 0.824 & & \\
\hline$L O Y A$ & 0.894 & 0.840 & 0.679 & 1.419 & 0.282 & 0.187 & 0.824 & \\
\hline DISC & 0.898 & 0.820 & 0.751 & 4.751 & 0.655 & 0.134 & 0.470 & 0.867 \\
\hline $\begin{array}{l}\text { DISC: disclosure } \\
\text { variance shared be } \\
\text { model provides a g } \\
\text { Gerbing (1988), } \\
\text { the minimum reco }\end{array}$ & $\begin{array}{l}\text {; social and fi } \\
\text { the constructs } \\
\text { to the data ba } \\
\text { dy uses Cronb } \\
\text { ed values of } 0 \text {. }\end{array}$ & $\begin{array}{l}\text { ial); SATIS: satisf } \\
\text { their measures. Off } \\
\text { on a number of fit s } \\
\text { s alpha coefficient a } \\
\text { nd } 0.5 \text {, respectively }\end{array}$ & $\begin{array}{l}\text { ion; TR } \\
\text { gonal elc } \\
\text { istics. A } \\
\text { the Ave }\end{array}$ & $\begin{array}{l}\text { trust and LOYA: loya } \\
\text { nts are the correlations } \\
\text { idence of internal reliab } \\
\text { V ariance Extracted } \\
\text { 010). }\end{array}$ & $\begin{array}{l}\text { The bold } \\
\text { ng constru } \\
\text { or consiste } \\
\text { E) Hair }\end{array}$ & $\begin{array}{l}\text { nal elem } \\
\text { esults st } \\
\text { of the cor } \\
\text {., } 2010\end{array}$ & $\begin{array}{l}\text { re the squ } \\
\text { ing that on } \\
\text {, and foll } \\
\text { values of }\end{array}$ & $\begin{array}{l}\text { of the } \\
\text { irement } \\
\text { inderson and } \\
\text { atistics exceed }\end{array}$ \\
\hline
\end{tabular}

Table 6: Testing of mediating models

\begin{tabular}{|l|l|l|l|l|}
\hline \multicolumn{1}{|c|}{ Path } & Based Model & \multicolumn{1}{|c|}{ Model 1 } & Model 2 & Full Model \\
\hline Disclosure $\rightarrow$ Loyalty & 0.18 & 0.36 & 0.27 & 0.46 \\
\hline Disclosure Satisfaction & & 0.86 & & 0.86 \\
\hline Satisfaction $\rightarrow$ Loyalty & & 0.22 & & 0.24 \\
\hline Disclosure $\rightarrow$ Trust & & & 0.22 & 0.22 \\
\hline Trust $\rightarrow$ Loyalty & & & 0.15 & 0.16 \\
\hline
\end{tabular}

\section{Figures}

Figure 1: Structural model estimation

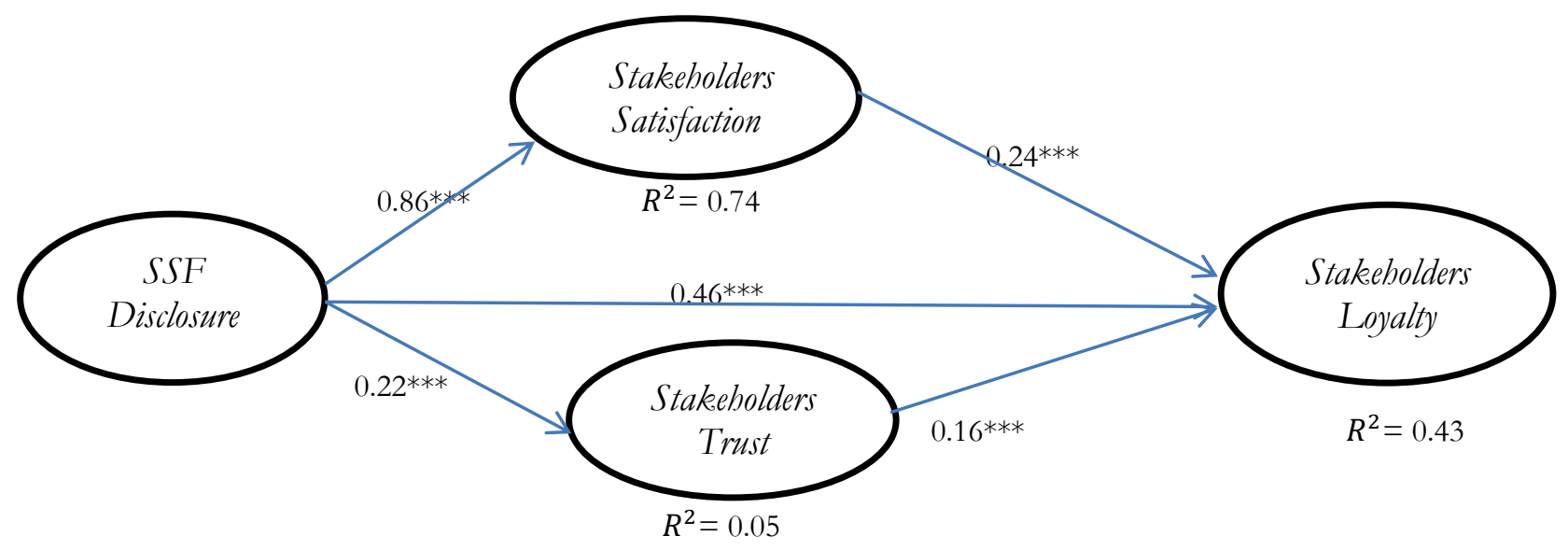

SSF Discolour: Sharia; Social and Financial disclosure

Note: The asterisks represent the significant level of the coefficient. ${ }^{*} 0.01 ;{ }^{* *} 0.05 ;{ }^{* * *} 0.001$

Figure (2) PLS results of research model of main test $(n=600)$

$\mathrm{APC}=(0.428, \mathrm{p}<0.001), \mathrm{ARS}=(0.405, \mathrm{p}<0.001), \mathrm{AARS}=(0.403, \mathrm{p}<0.001), \mathrm{AVIF}=(2.821)$, and

$\mathrm{GOF}=(0.515)$ 